NOTE

\title{
First identification of Flavobacterium columnare infection in farmed freshwater striped catfish Pangasianodon hypophthalmus
}

\author{
Nguyen Thi Tien ${ }^{1}$, Tu Thanh Dung ${ }^{1}$, Nguyen Anh Tuan ${ }^{1}$, Mags Crumlish ${ }^{2, *}$ \\ ${ }^{1}$ College of Aquaculture Fisheries, Cantho University, Cantho City, Vietnam \\ ${ }^{2}$ Institute of Aquaculture, Stirling University, Stirling FK9 4LA, UK
}

\begin{abstract}
The bacterium Flavobacterium columnare was recovered and identified as the aetiological agent causing freshwater columnaris infection in farmed striped catfish Pangasianodon hypophthalmus (Sauvage) fingerlings that had suffered high mortality rates within commercial hatchery ponds in Vietnam. The gross clinical signs were typical of columnaris-infected fish. Histological examination found numerous Gram-negative, filamentous bacteria present on the skin, muscle and gill tissues of affected fish. The yellow-pigmented bacteria were isolated and identified as F. columnare using primary, biochemical and PCR methods. An experimental immersionchallenge study with 2 strains was also performed. It fulfilled Koch's postulates and showed a median lethal concentration $\left(\mathrm{LC}_{50}\right)$ of $4.27 \times 10^{5}$ and $1.66 \times 10^{6} \mathrm{cfu} \mathrm{m}^{-1}$ for the $F$. columnare strains FC-HN and FC-CT, respectively. To the best of our knowledge this is the first report of freshwater columnaris infection in P. hypophthalmus.
\end{abstract}

KEY WORDS: Flavobacterium columnare $\cdot$ White patch disease $\cdot$ Pangasianodon hypophthalmus

\section{INTRODUCTION}

The bacterium Flavobacterium columnare is a Gram-negative rod, displaying gliding motility, and has been reported as the aetiological agent of freshwater columnaris disease, which affects a wide range of freshwater fish globally (Anderson \& Conroy 1969). The disease presents grossly as external lesions that may or may not become ulcerated. The body, head, gills and fins are the more favoured sites for bacterial attachment, observed grossly as white spots or necrotic areas during an active infection. Ultimately, bacterial colonisation leads to tissue erosion (Wakabayashi 1993). Although the clinical signs are not pathognomonic for the disease, affected fish more commonly present with tail erosion, whitish spots on the body and greyish gills (Shotts \& Starliper 1999, Pilarski et al. 2008). F. columnare have been more commonly isolated from the external surfaces of affected animals (Foscarini 1989, Austin \& Austin 1993, McElwain et al. 2009). This bacterium is not thought to be associated with a systemic infection and is not normally recovered from the internal organs. At present, the striped catfish Pangasianodon hypophthalmus (Sauvage) industry in Vietnam is progressing well, with an estimated 1.2 million t produced in 2010 (Sinh \& Hien 2010). However, recent high mortalities approaching $100 \%$ of $P$. hypophthalmus fingerlings have been reported in commercial hatcheries. The affected fish presented clinically 
with similar signs to those described for columnaris infections in other fish species. Outbreaks of $F$. columnare in $P$. hypophthalmus have not yet been reported from Vietnam or elsewhere, and so the aim of the present study was to investigate the disease and identify the aetiological agent associated with the high fingerling mortalities in Vietnamese $P$. hypophthalmus hatcheries. An experimental bacterial challenge study was also completed to confirm Koch's postulates and to determine the median lethal concentration $\left(\mathrm{LC}_{50}\right)$ for 2 different $F$. columnare strains on $P$. hypophthalmus.

\section{MATERIALS AND METHODS}

A total of 83 Pangasianodon hypophthalmus (weighing 3 to $20 \mathrm{~g}$ ) were collected during natural disease outbreaks from 5 hatchery and 7 earthen pond farms located in Vietnam. Histology samples of the skin, gill, kidney, liver and spleen were aseptically removed, placed in $10 \%$ (v/v) neutral buffered formalin and processed for routine wax sections. Four-micron thick sections were cut and stained with haematoxylin and eosin (H\&E) and Giemsa (Roberts 1989). These were examined under light microscopy. Bacterial isolation was performed where samples were taken aseptically from gills, skin, liver, kidney and spleen of the affected animals directly onto peptone, yeast extract, salt and agar (PYES) (Triyanto \& Wakabayashi 1999) and tryptone soy agar (TSA; Oxoid) and then incubated at $28^{\circ} \mathrm{C}$. Inoculated agar plates were checked daily up to $4 \mathrm{~d}$ post-inoculation for the presence of yellow-pigmented colonies, and primary identification tests included Gram stain, oxidase, oxidation/fermentation (O/F) of glucose, and motility, as described in Frerichs \& Millar (1993). Biochemical tests on the yellow-pigmented bacteria (YPB) included catalase, temperature tolerance (13, 15 and $\left.36^{\circ} \mathrm{C}\right), \mathrm{NaCl}$ tolerance $(0.5$ and $1 \%)$, citrate utilisation, production of indole, hydrolysis of starch and urea, utilisation of carbohydrate (mannitol, glucose and glycerol), production of gelatinase, nitrate reduction following Cowan \& Steel (Barrow \& Feltham 1993), production of flexirubin pigments following Reichenbach et al. (1981) and absorption of Congo red dye (Janda et al. 1991). All these tests were incubated at $28^{\circ} \mathrm{C}$ for $48 \mathrm{~h}$ unless otherwise stated. DNA was extracted from bacterial samples recovered from affected fish that were preliminarily identified as Flavobacterium columnare following slight modification of methods described in Farmer (2004). Briefly, $2 \mathrm{ml}$ of the bacterial suspension in
PYES broth was centrifuged at $13000 \times g$ for 5 min and the supernatant discarded. One hundred microlitres of lysis buffer (10 Mm Tris $\mathrm{HCl}, \mathrm{pH}$ 8.0) and $100 \mu \mathrm{l}$ of $10 \%$ sodium dodecyl sulphate (SDS) was added to the cell pellet, which was then incubated at $37^{\circ} \mathrm{C}$ for $30 \mathrm{~min}$. After this time, $20 \mu \mathrm{l}$ of Proteinase $\mathrm{K}$ $\left(20 \mathrm{mg}^{-1}\right.$ ) was added and then incubation followed for $1 \mathrm{~h}$ at $37^{\circ} \mathrm{C}$. Then $100 \mu \mathrm{l}$ of $5 \mathrm{M} \mathrm{NaCl}$ and $100 \mu \mathrm{l}$ of hexadecyltrimethylammonium bromide (CTAB) was added to the solution, which was mixed and incubated at $65^{\circ} \mathrm{C}$ for $20 \mathrm{~min}$. Six hundred microlitres of chloroform-isoamyl alcohol (24:1) was added, and the solution was mixed and centrifuged at $13000 \times g$ for $10 \mathrm{~min}$. This step was repeated, and then the lower layer was removed to a new sterile tube and rinsed with $600 \mu \mathrm{l}$ of $70 \%$ ethanol and centrifuged at $13000 \times g$ for $2 \mathrm{~min}$, and the DNA was left to air-dry. A 16S ribosomal DNA PCR assay described by Panangala et al. (2007) followed. Each $25 \mu$ PCR reaction contained a Master mix $(10 \times$ buffer, $10 \mu \mathrm{M}$ dNTP, $25 \mathrm{mM} \mathrm{MgCl}_{2}$ and $5 \mathrm{U}$ Taq DNA polymerase; all Merck), $0.6 \mu \mathrm{M}$ of each primer FcFd and FcRs and between 230 and 640 ng of bacterial DNA. The primer sets FcFd and FcRs described in Panangala et al. (2007) were used. The positive control was F. columnare strain NCIMB 2248, and all PCR products were subjected to electrophoresis with $3 \%(\mathrm{w} / \mathrm{v})$ agarose gel and ethidium bromide $\left(5 \mu \mathrm{g} \mathrm{m} \mathrm{m}^{-1}\right)$. The expected target PCR products were $504 \mathrm{bp}$ in length.

Finally, an $\mathrm{LC}_{50}$ experiment was performed where 300 Pangasianodon hypophthalmus fingerlings (weighing 3 to $6 \mathrm{~g}$ ) were transported from a commercial hatchery to the challenge site. The fish were acclimatised for $10 \mathrm{~d}$ before challenge and were fed daily with a commercial feed at $2 \%$ body weight, maintained at 28 to $30^{\circ} \mathrm{C}$ and given approximately $10 \%$ water changes daily. Prior to bacterial challenge, approximately $5 \%$ of the 300 fingerlings were screened for the presence of parasites and bacteria using routine gross microscopy and traditional bacterial recovery methods as a guide to checking their health status before selection into treatment groups. Two Flavobacterium columnare isolates identified as FC-HN and FC-CT were used for the challenge studies. These bacterial strains had been recovered from the skin of moribund P. hypophthalmus with clinical signs of columnaris infection and had been identified as $F$. columnare by bacterial identification tests and PCR assay, as described in the previous paragraph. These challenge isolates were grown in PYES broth to log-phase growth and washed twice with sterile $0.85 \%(\mathrm{w} / \mathrm{v}) \mathrm{NaCl}$, and viable bacterial colony counts were performed using the Miles \& Misra method 
(Miles et al. 1938). A range of bacterial concentrations $\left(1.7 \times 10^{7}, 1.7 \times 10^{6}\right.$ or $1.7 \times 10^{5} \mathrm{cfu} \mathrm{ml}^{-1}$ for strain FC-HN; $3.2 \times 10^{7}, 3.2 \times 10^{6}$ or $3.2 \times 10^{5} \mathrm{cfu} \mathrm{ml}^{-1}$ for strain FC-CT) were given to the fish by immersion for $60 \mathrm{~min}$. These were the actual bacterial concentrations in the water. Each treatment group had 15 apparently healthy $P$. hypophthalmus randomly allocated, with 2 replicate tanks per bacterial strain and concentration. The control fish were treated in the same way but were not given any bacteria. The challenge lasted for $10 \mathrm{~d}$ and during this time the fish were not fed. Moribund fish were examined and sampled for histopathology and bacterial recovery onto PYES agar as described in the previous paragraph. These re-isolated bacterial strains after challenge were compared with $2 F$. columnare used for challenge by biochemical characteristics and PCR.

\section{RESULTS}

All of the infected fish collected from the natural outbreaks showed clinical signs (Fig. 1A) similar to those previously described in the published literature for columnaris infections. An attempt was made to separate the fish into acute and chronically infected, where in the acute stage, fish had tail erosion, necrotic patches on the gills and increased mucus production over the body. Chronically infected fish had tail erosion, complete discoloration or necrosis of the gills and typical saddleback/patch lesions. A total

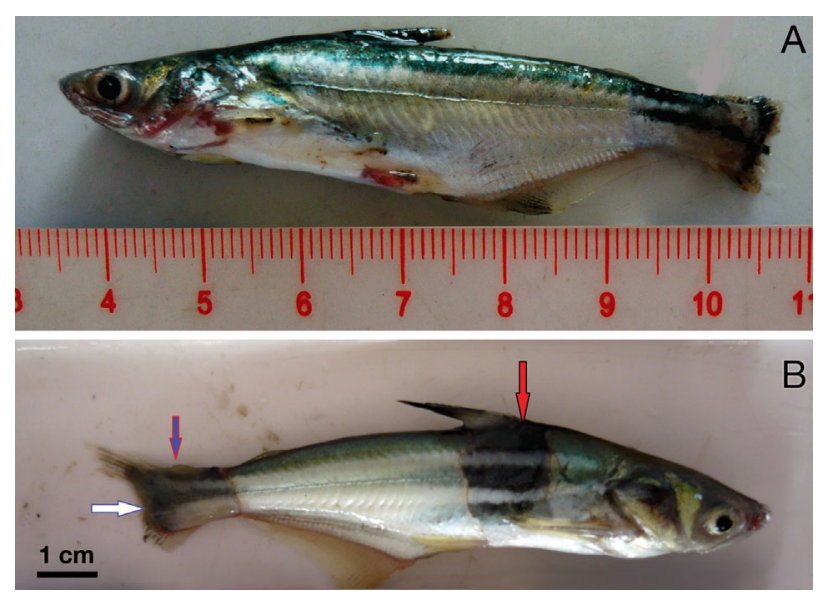

Fig. 1. Flavobacterium columnare infecting Pangasianodon hypophthalmus. (A) Gross presentation of affected P. hypophthalmus during natural outbreak of $F$. columnare. Ruler shows $\mathrm{cm}$. (B) Gross presentation of typical saddleback lesion on $P$. hypophthalmus observed at $84 \mathrm{~h}$ post-bacterial exposure with $F$. columnare strain $\mathrm{FC}-\mathrm{HN}$ at $10^{6} \mathrm{cfu} \mathrm{ml}^{-1}$. Patch on the dorsal area (red arrow), tail erosion (white arrow) and development of an ulcer (blue arrow) are indicated of 83 YPB isolates were recovered onto PYES agar from the naturally infected moribund fish, in which 5 different colony morphologies were observed (data not presented). The YPB were recovered from the external organs (skin and gill) of moribund fish in every hatchery and farm during sampling. These were only recovered from fish with clinical signs of disease and not from apparently healthy animals. All of the YPB recovered were identified as Gramnegative, long flexible rods, oxidase- and catalasepositive, and oxidative on O/F. They showed gliding motility, and growth was recorded between 15 and $36^{\circ} \mathrm{C}$ and at $0.5 \% \mathrm{NaCl}$ only. The YPB were positive for production of flexirubin-type pigments and Congo red, gelatin hydrolysis and reduced nitrate, were acid-negative from carboxylases, citrate, starch and indole and negative for urease. These characteristics were similar to those of the positive control strain Flavobacterium columnare NCIMB 2248.

The fish used in the challenge experiment had no obvious signs of disease and only those regarded as apparently healthy were used in the challenge experiment. Mortalities/morbidities only occurred in the experimental groups that had received the bacteria. The cumulative percentage daily mortalities are shown in Fig. 2. The $\mathrm{LC}_{50}$ of strain FC-HN was $4.27 \times$ $10^{5} \mathrm{cfu} \mathrm{ml}^{-1}$ and for strain FC-CT it was $1.66 \times 10^{6} \mathrm{cfu}$ $\mathrm{ml}^{-1}$ (Fig. 2). The moribund/dead fish in the experimental challenge study had gross clinical signs similar to those on the naturally infected fish. The acute fish mortalities were considered as those that occurred within $24 \mathrm{~h}$ post-bacterial exposure, and these fish swam continually with convulsions at the water surface, particularly apparent in the first few hours post-bacterial exposure. In these fish, the skin and gill mucus layer increased quickly and was a transparent white colour, but disappeared prior to death. In these fish, the gills became a deep red colour with alternate white patches. These fish also had de-pigmented patches on the body, with a yellowish discoloration on the fins. Latterly they had more severe tail erosion and the gills were completely necrotic. It was only in the mortalities post $24 \mathrm{~h}$ that the affected fish had typical presentation of saddle patch (Fig. 1B). Strain variation in the behaviour of the mortalities in the experimental challenge study was also observed, where the fish given strain FC-CT died but did not display the same swimming or convulsive behaviour as observed for those animals exposed to strain FC-HN. Fish in the control group did not present with any clinical signs of disease during the study. Bacteria recovered from the experimental challenge fish were all identified as 


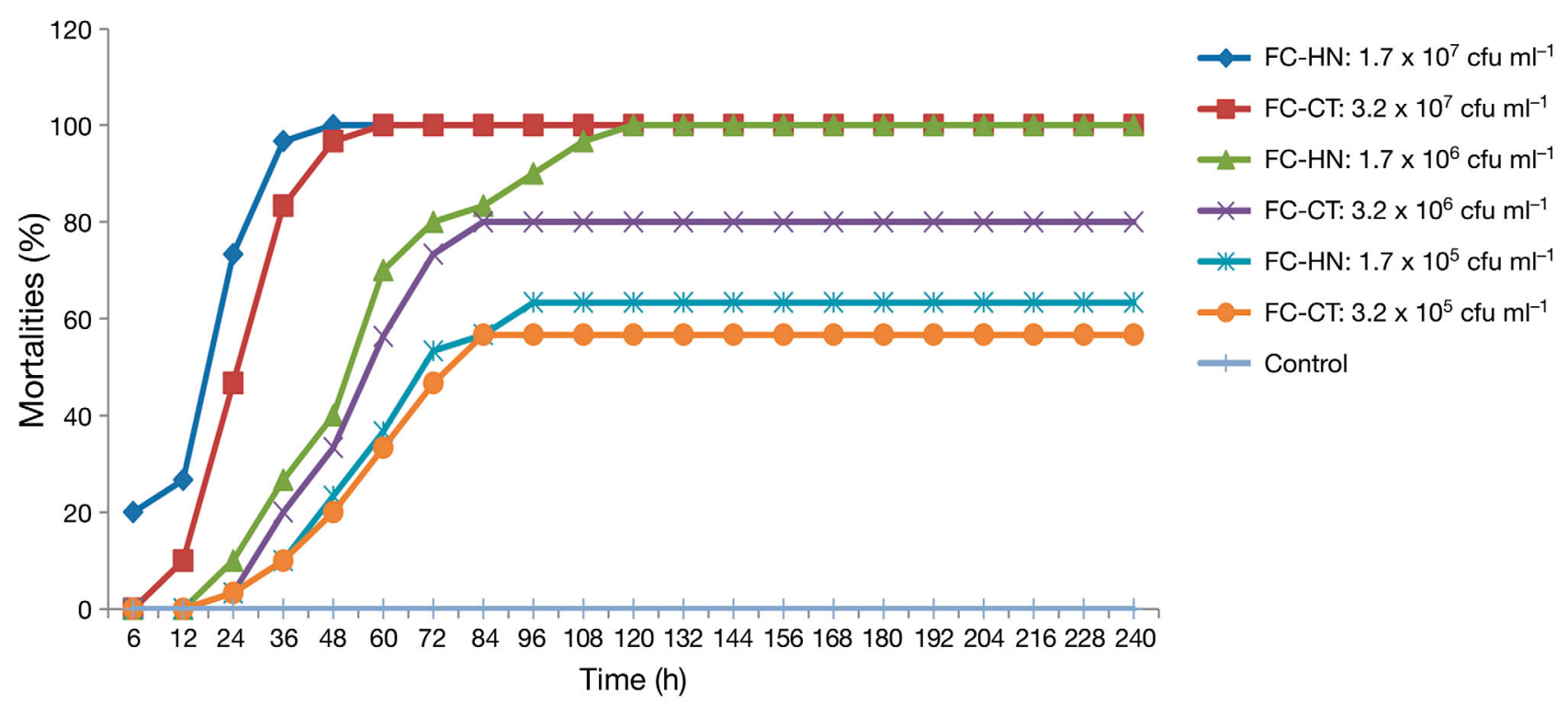

Fig. 2. Flavobacterium columnare infecting Pangasianodon hypophthalmus. Cumulative percentage daily mortality of fish in experimental median lethal concentration $\left(\mathrm{LC}_{50}\right)$ challenge. FC-HN, FC-CT: F. columnare strains isolated in moribund $P$. hypothalmus from Dongthap province and Cantho province, respectively

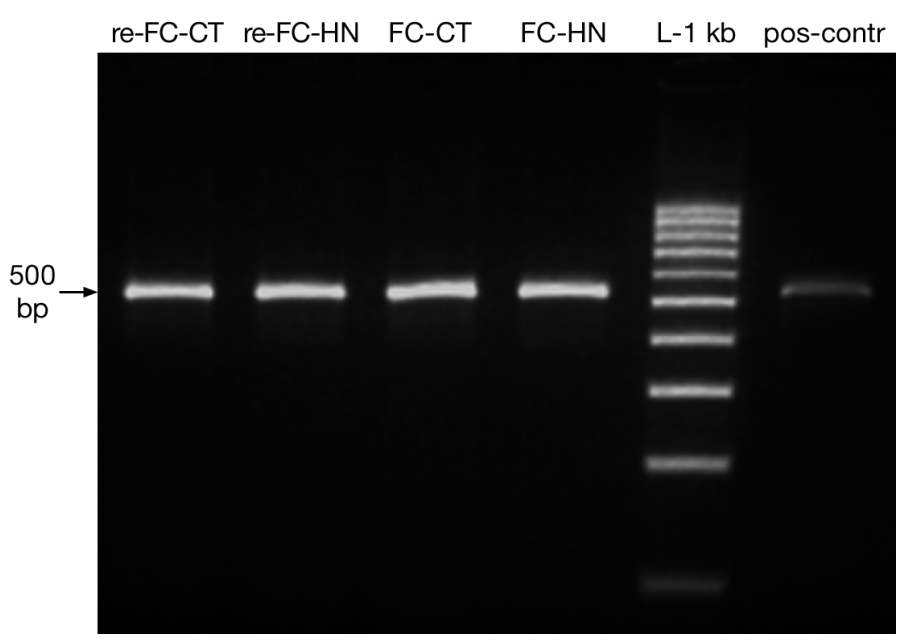

Fig. 3. Flavobacterium columnare infecting Pangasianodon hypophthalmus. 16S rDNA PCR results. Lane re-FC-CT: F. columnare strain FC-CT (re-isolate from affected fish in challenge group $2\left(3.2 \times 10^{6} \mathrm{cfu} \mathrm{ml}^{-1}\right)$; Lane re-FC-HN: F. columnare strain FC-HN (re-isolate from affected fish in challenge group $2\left(1.7 \times 10^{6} \mathrm{cfu} \mathrm{ml}^{-1}\right)$; Lane FC-CT: F. columnare challenge strain FC-CT; Lane FC-HN: F. columnare challenge strain FC-HN; Lane L-1 kb: molecular weight ladder; Lane pos-contr: positive control (F. columnare strain NCIMB 2248)

described previously and gave similar profiles to the challenge strains. These were also positive for Flavobacterium columnare using the PCR assay (Fig. 3). Similar histopathological observations were found in the experimentally challenged fish with clinical signs of disease as those observed in natural infections. The presence of long slender Gram-negative rods were visible in the epidermis and dermis of the fish with associated breakdown of collagen and intermixed between bacteria (blue-violet slender long) and collagen in skin. The muscle tissue had high leucocyte influx associated with the presence of F. columnare (Fig. 4).

\section{DISCUSSION}

In the present study we have confirmed the natural disease outbreaks of Flavobacterium columnare infection in hatchery-farmed Pangasianodon hypophthalmus produced in Vietnam. Clinically, the affected $P$. hypophthalmus observed in the present study all showed typical signs of columnaris infection as reported previously for other fish species (Austin \& Austin 1993, Decostere 1999, Shotts \& Starliper 1999, Tripathi et al. 2005). In the present study, the bacteria recovered were identified as F. columnare, and this aquatic pathogen was isolated only from the affected fish sampled in each of the farm sites recovered during the natural outbreaks. An experimental immersion-challenge study was performed in an attempt to fulfill Koch's postulates and to determine the $\mathrm{LC}_{50}$ dose. In the present study, fish exposed to high bacterial loads all died between 48 and $52 \mathrm{~h}$ post-exposure, which was similar to findings of previous reports for this bacterial pathogen (Michel et al. 2002, ThomasJinu \& Goodwin 2004). The mortality rates may vary 

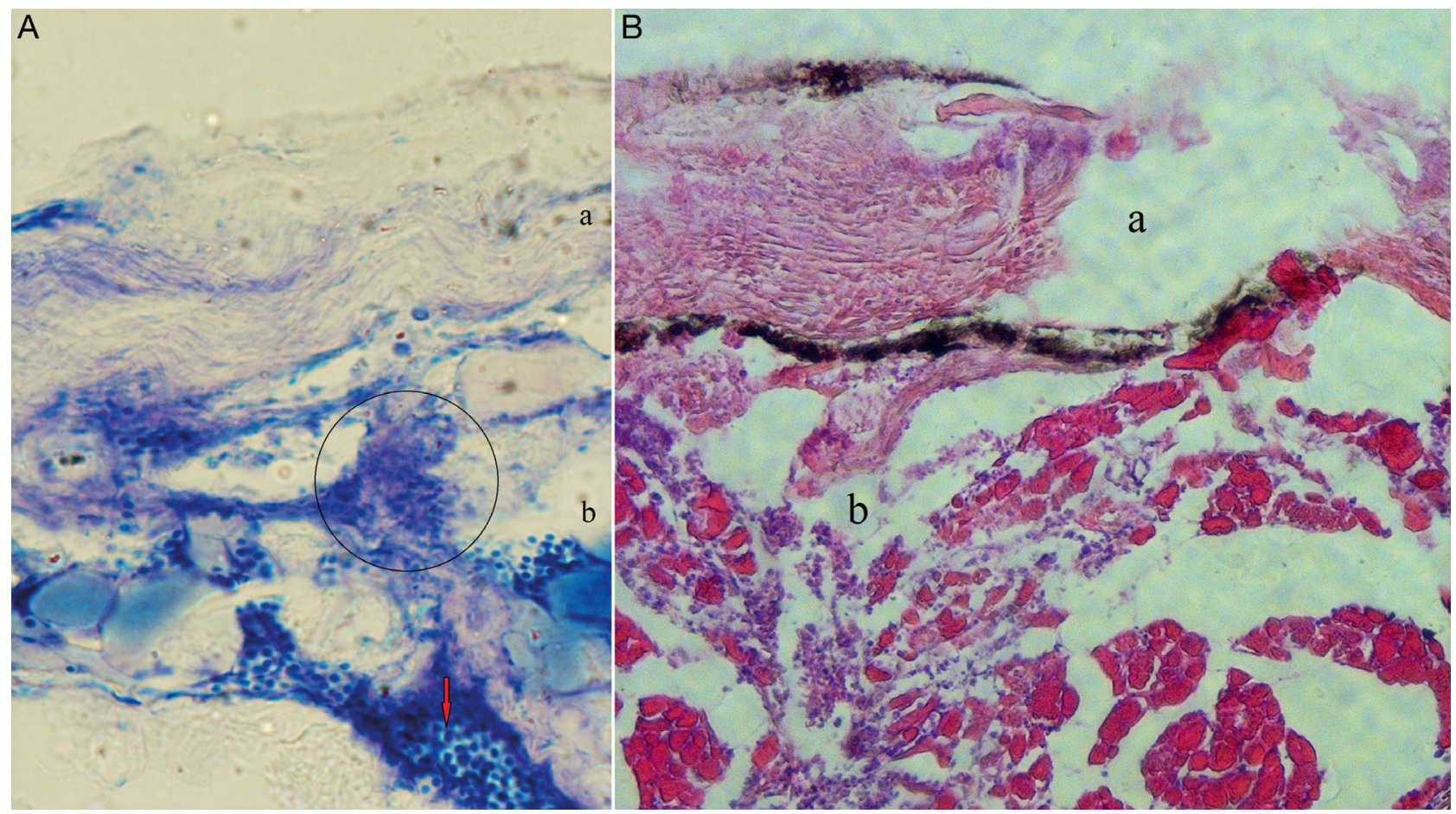

Fig. 4. Flavobacterium columnare infecting Pangasianodon hypophthalmus. (A) Giemsa stain section ( $\times 1000$ magnification) of moribund fish from experimental challenge study ( $F$. columnare strain FC-HN) at $10^{6} \mathrm{cfu} \mathrm{ml}^{-1}$ taken $84 \mathrm{~h}$ post-bacterial exposure. a: loss of structure in the skin showing flexible bacteria intermixed with collagen; b: necrosis of muscle areas where the circled area represents white blood cell influx and F. columnare; red arrow highlights presence of white blood cells.

(B) H\&E stain section ( $\times 1000$ magnification). a: loss of the skin layer; b: area of cellular necrosis in the muscle

due to virulence expression of the different bacterial strains as well as varied host response. This was also found in the present study but the differences observed in the mortality rate were not statistically evaluated, and further work is required to fully explore differences in virulence factors associated with Vietnamese $F$. columnare strains, where studies similar to those reported by Decostere et al. (1999) and Craig \& Hargreaves (2004) could be conducted. The colony morphologies observed from the different Vietnamese $F$. columnare were in agreement with descriptions reported by Bader et al. (2005), Pilarski et al. (2008) and Kunttu et al. (2009). All yellow-pigmented isolates in the present study, whether originating from natural outbreaks or recovered from experimental challenge, were identified as F. columnare using bacterial identification tests and confirmed using $16 \mathrm{~S}$ rDNA PCR. Pathology samples from both naturally and experimentally infected $P$. hypophthalmus showed extensive damage to skin, gills and muscle, which is similar to previous studies in other fish species. Gill damage was observed in naturally and experimentally infected fish, which would have compromised respiration, observed as behavioural changes in P. hypophthalmus. The gill necrosis and bacterial presence observed in $P$. hypophthalmus was similar to that described by Decostere (1999) in black molly. The presence of the bacteria on the skin is typical of columnaris infections, resulting in skin and muscle injury with inflammatory cell influx. These observations in $P$. hypophthalmus were similar to those reported by Tripathi et al. (2005) for carp Cyprinus carpio. To our knowledge this is the first report of this bacterial infection in farmed P. hypophthalmus in Vietnam. The prevalence of this disease within the Vietnamese striped catfish industry is yet unclear but the present study has shown that F. columnare is present within the Vietnamese industry and can cause morbidity and death.

\section{LITERATURE CITED}

Anderson JIW, Conroy DA (1969) The pathogenic myxobacteria with special reference to fish disease. J Appl Bacteriol 32:30-39

Austin B, Austin DA (eds) (1993) Bacterial fish pathogens: diseases of farmed and wild fish. Springer-Praxis Series in Aquaculture \& Fisheries published in association with Praxis Publishing, Chichester 
Bader JA, Shoemaker CA, Klesius PH (2005) Production, characterization and evaluation of virulence of an adhesion defective mutant of Flavobacterium columnare produced by $\beta$-lactam selection. Lett Appl Microbiol 40: 123-127

Barrow GI, Feltham RKA (1993) Cowan \& Steel's manual for the identification of medical bacteria. Cambridge University Press, Cambridge

Craig ST, Hargreaves JA (2004) Biology and culture of channel catfish. Elsevier, Amsterdam

Decostere A (1999) Flavobacterium columnare infection in fish: the agent and its adhesion to the gill tissue. $\mathrm{PhD}$ dissertation, University of Ghent

Decostere A, Haesebrouck F, Charlier G, Ducatelle R (1999) The association of Flavobacterium columnare strains of high and low virulence with gill tissue of black mollies (Poecilia sphenops). Vet Microbiol 67:287-298

Farmer B (2004) Improved methods for the isolation and characterization of Flavobacterium columnare. MSc dissertation, Northwestern State University, Natchitoches, LA

Foscarini R (1989) Induction and development of bacteria gill disease in the eels (Anguilla japonica) experimentally infected with Flexibacter columnaris: pathological changes in the gill vascular structure and in cardiac performance. Aquaculture 78:1-20

Frerichs GN, Millar SD (1993) Manual for the isolation and identification of fish bacterial pathogens. Pisces Press, Stirling

> Janda JM, Abbot SL, Kroske-Bystrom S, Cheung WK, Powers C, Kokka RP, Tamura K (1991) Pathogenic properties of Edwardsiella species. J Clin Microbiol 29:1997-2001

Kunttu HMT, Suomalainen L, Jokinen EI, Valtonen ET (2009) Flavobacterium columnare colony types: connection to adhesion and virulence? Microb Pathog 46:21-27

McElwain A, Olivares-Fuster O, Arias CR, Bullard SA (2009) Preliminary observations of pathological changes to skin and gill of channel catfish (Ictalurus punctatus) and zebra danio (Danio rerio) exposed to Flavobacterium columnare. In: Proceedings of the Second International Flavobacterium Workshop, Paris

Michel C, Messiaen S, Bernardet JF (2002) Muscle infections in imported neon tetra, Paracheirodon innesi

Editorial responsibility: David Bruno,

Aberdeen, UK
Myers: limited occurrence of microsporidia and predominance of severe forms of columnaris disease caused by an Asian genomovar of Flavobacterium columnare. J Fish Dis 25:253-263

Miles AA, Misra SS, Irwin JO (1938) The estimation of the bactericidal power of the blood. J Hyg 38:732-749

> Panangala VS, Shoemaker CA, van Santen VL, Dybvig K, Klesius PH (2007) Multiplex-PCR for simultaneous detection of 3 bacterial fish pathogens, Flavobacterium columnare, Edwardsiella ictaluri, and Aeromonas hydrophila. Dis Aquat Org 74:199-208

Pilarski F, Rossini AJ, Ceccarelli PS (2008) Isolation and characterization of Flavobacterium columnare from four tropical fish species in Brazil. Braz J Biol 68:409-414

Reichenbach H, Kohl W, Achenbach H (1981) The flexirubintype pigments, chemosystematically useful compounds. In: Reichenbach H, Weeks OB (eds) Proceedings of the International Symposium on Yellow Pigmented Gramnegative Bacteria of the Flavobacterium-Cytophaga Group. Verlag Chemie, Deerfield Beach, FL, p 681

Roberts RJ (1989) Fish pathology, 2nd edn. Ballure Tindal, London

Shotts EB, Starliper CE (1999) Flavobacterial diseases: columnaris disease, cold-water diseases and bacterial gill disease. In: Woo PT, Bruno DW (eds) Viral, bacterial and fungal infections. CAB International, Wallingford, p 599-576

Sinh LX, Hien LL (2010) Supply and use of catfish (Pangasianodon hypophthalmus) in the Mekong delta of Vietnam. Res Farming Tech 15(1):26-33

Thomas-Jinu S, Goodwin AE (2004) Morphological and genetic characteristics of Flavobacterium columnare isolates: correlations with virulence in fish. J Fish Dis 27: 29-35

> Tripathi NK, Latimer KS, Gregory CR, Ritchie BW, Wooley RE, Walker RL (2005) Development and evaluation of an experimental model of cutaneous columnaris disease in koi Cyprinus carpio. J Vet Diagn Invest 17:45-54

Triyanto, Wakabayashi H (1999) Genotypic diversity of strains of Flavobacterium columnare from diseased fishes. Fish Pathol 34:65-71

Wakabayashi H (1993) Columnaris disease. In: Inglis V, Roberts RJ, Bromage N (eds) Bacterial diseases of fish. Halsted Press, London, p 23-39

Submitted: July 6, 2011; Accepted: April 18, 2012

Proofs received from author(s): July 26, 2012 